\title{
CHEMOTYPIC OF ROSMARINUS OFFICINALIS L. ESSENTIAL OILS FROM EASTERN SIDE OF IRAQ
}

\author{
SARAH ALI HAMID* \\ Faculty of Pharmacy, Uruk University, Baghdad, Iraq. Email: sarah_alsayed@uruk.edu.iq \\ Received: 16 December 2019, Revised and Accepted: 08 January 2020
}

\begin{abstract}
Objective: The purpose of this study was to identify and characterize chemical constituents of Rosmarinus officinalis L. essential oils from Diyala Province, an eastern side of Iraq.
\end{abstract}

Methods: Following hydrodistillation extraction of the leaves, gas chromatography-mass spectrometry (MS) was performed. Eighteen peaks were identified and compared to known compounds and MS patterns.

Results: The two major components identified were eucalyptol (1,8-cineole) and L-camphor, and they represent 59\% and 29\%, respectively. In addition, $\alpha$-terpineol, bornyl acetate, borneol, linalool, and $\beta$-terpineol were detected in $3.75,2.83,1.96,1.22$, and $0.65 \%$, respectively.

Conclusion: The present study showed that rosemary essential oils from Diyala Province of Iraq consisted mostly of oxygenated monoterpenes $(>96 \%)$ and hydrocarbon monoterpenes are less than 1\%. The latter suggest that hydrocarbon monoterpenes may undergo transformation due to atmospheric as well as microbiological metabolism which more studies are needed to confirm such suggestion.

Keywords: Rosmarinus officinalis L., essential oil, Gas chromatography-mass spectrometry, Hydrodistillation, Oxygenated monoterpenes, Diyala.

(C) 2020 The Authors. Published by Innovare Academic Sciences Pvt Ltd. This is an open access article under the CC BY license (http://creativecommons. org/licenses/by/4. 0/) DOI: http://dx.doi.org/10.22159/ajpcr.2020.v13i3.36635

\section{INTRODUCTION}

Rosmarinus officinalis L. is an aromatic plant from the Lamiaceae family, and the primary origin is the Mediterranean area, but also it is cultured around the world [1-3]. Rosemary is mostly used as a spice in food preparation and as a food preservative. Furthermore, rosemary extract and its essential oil have been used in herbal medicine as antioxidant, antimicrobial, and anti-inflammatory agents [1-3]. Besides, one of the major constituents of rosemary essential oil such as eucalyptol has been shown to have great potential in treating chronic inflammatory diseases [4]

Many studies have determined the chemical constituents of $R$. officinalis essential oils, leaves and flowers grown in different countries and geographical origins. Each of these studies showed variations in the constituents within the monoterpenes and oxygenated monoterpenes [5-7]. Similarly, two studies from two different locations in the Baghdad, capital of Iraq, have been performed to identify the chemical constituents of the rosemary leaves essential oil and presented significant variations in the percentage constituents, as well as in the chemical identification of monoterpenes and oxygenated monoterpenes. For instance, one study obtained a high percentage of oxygenated monoterpenes, linalool (11.58\%), whereas the other second did not report any $[8,9]$. Therefore, it is essential to characterize the chemical constituents of rosemary essential oils in different geographical locations within the same country.

Since (a) the demand of using the essential oil of $R$. officinalis in complementary medicine as well as in the food and pharmaceutical industry and (b) the constituents varied between countries and within the same country's geographical areas, it is determined to establish the chemical constituents of rosemary essential oil from Diyala Province, an agricultural industry with $7685 \mathrm{~km}^{2}$ area, in the eastern side of Iraq, northeast of Baghdad. Furthermore, the present study compares the rosemary essential oil constituents from similar geographical areas as well as different world locations.

\section{METHODS}

\section{Plant material}

Rosemary samples were harvested during October 2017 from the Diyala Province of the eastern side of Iraq, which has the following coordinates: $33^{\circ} 53^{\prime} \mathrm{N} 45^{\circ} 4^{\prime} \mathrm{E}$. The samples consisted of the leaves parts, washed extensively with tap water, and kept drying for 7 days. Identification of the leaves was performed by microscopic investigations, and a voucher specimen is retained under the code AATR1 at Faculty of Pharmacy, Uruk University, Baghdad, Iraq.

\section{Extraction of essential oils}

The extraction method used was hydrodistillation using a Clevenger apparatus. Briefly, a $100 \mathrm{~g}$ of Rosemary leaves sample was immersed in $800 \mathrm{ml}$ distilled water in a $2 \mathrm{~L}$ round bottom flask. The mixture was put in heated mantel to boil, and then, hydrodistillation is performed for $3 \mathrm{~h}$. The samples were boiled with water and the volatile oils evaporated along with the water into the condenser connected to a flask at $100^{\circ} \mathrm{C}$ and atmospheric pressure. To prevent overheating, however, the heating mantel was then set to $60^{\circ} \mathrm{C}$. At the end of the distillation, a less dense phase than water (essential oil) and an aqueous phase were established. The oil phase was collected, dried, and stored in sealed vials. To remove the traces of water in the essential oils, $1 \mathrm{~g}$ of magnesium sulfate was added. The vials were kept in the dark at $4^{\circ} \mathrm{C}$ until used. The extraction method was repeated twice.

\section{Yield of essential oils}

The percentage yield of rosemary essential oil form the above extraction method was calculated from the equation below:

Percentage yield of essential oils $=\frac{\text { Amount of oil extracted }(\mathrm{g})}{\text { Amount of dry powder }(\mathrm{g})} \times 100$

Chromatographic analyses of essential oils

Following extraction, identification of chemical constituents of the rosemary essential oils was performed by gas chromatography 
coupled with mass spectrometry (GC-MS) (Shimadzu, GCMSQP2010 Ultra, Tokyo, Japan). The column used was a $30 \mathrm{~m} \times$ $0.25 \mathrm{~mm}$ with an internal diameter and film thickness of 0.25 $\mu \mathrm{m}$, with helium as a carrier gas. The instrument was set to the following: Column oven temperature was initially set at $70^{\circ} \mathrm{C}$ and then gradually increased within minutes to $240^{\circ} \mathrm{C}$; injection temperature: $240^{\circ} \mathrm{C}$; sampling time: $1.0 \mathrm{~min}$; pressure: $100.0 \mathrm{kPa}$; total flow: $19.9 \mathrm{~mL} / \mathrm{min}$; column flow: $1.53 \mathrm{~mL} / \mathrm{min}$; linear velocity: $45.4 \mathrm{~cm} / \mathrm{s}$; purge flow: $3.0 \mathrm{~mL} / \mathrm{min}$; and split ratio: 10.0 . As for the GC-MS program, it was set to ion source temperature: $200.00^{\circ} \mathrm{C}$; interface temperature: $240.00^{\circ} \mathrm{C}$; solvent cut time: $4.00 \mathrm{~min}$; ionization mode: SEI; detector gain mode: Relative; detector gain: $1.20 \mathrm{kV}+0.00 \mathrm{kV}$; start time: $4.50 \mathrm{~min}$; end time: $27.00 \mathrm{~min}$; event time: $0.30 \mathrm{~s}$; scan speed: 2500; start m/z: 45.00; and end m/z: 700.00. The MS pattern of each constituent was compared and matched with MS patterns of known compounds and with those of other essential oils using the database library of the National Institute of Standards and Technology (NIST08).

\section{RESULTS AND DISCUSSION}

The hydrodistillation extraction method revealed $0.7 \%$ of essential oils from $R$. officinalis leaves. It has been shown that increasing heating time would increase the amount of essential oil extracted. For instance, heating for 20-70 min extracts $0.2-0.6 \%$, whereas heating for $180 \mathrm{~min}$ acquires $1.4-4 \%$ of essential oils $[10,11]$. However, in the present study, the heating time was $180 \mathrm{~min}$, but the amount yield was low than expected. This may be related to the rosemary plant grown in Diyala Province of the eastern side of Iraq which has also been known not to produce flowers.

The gas chromatography profile of the extracted oils showed 18 peaks in a 20 min scan time (Fig. 1).

Following MS fragmentation pattern and comparison of each to known compounds, the 18 components of the essential oils were identified and presented in Table 1.

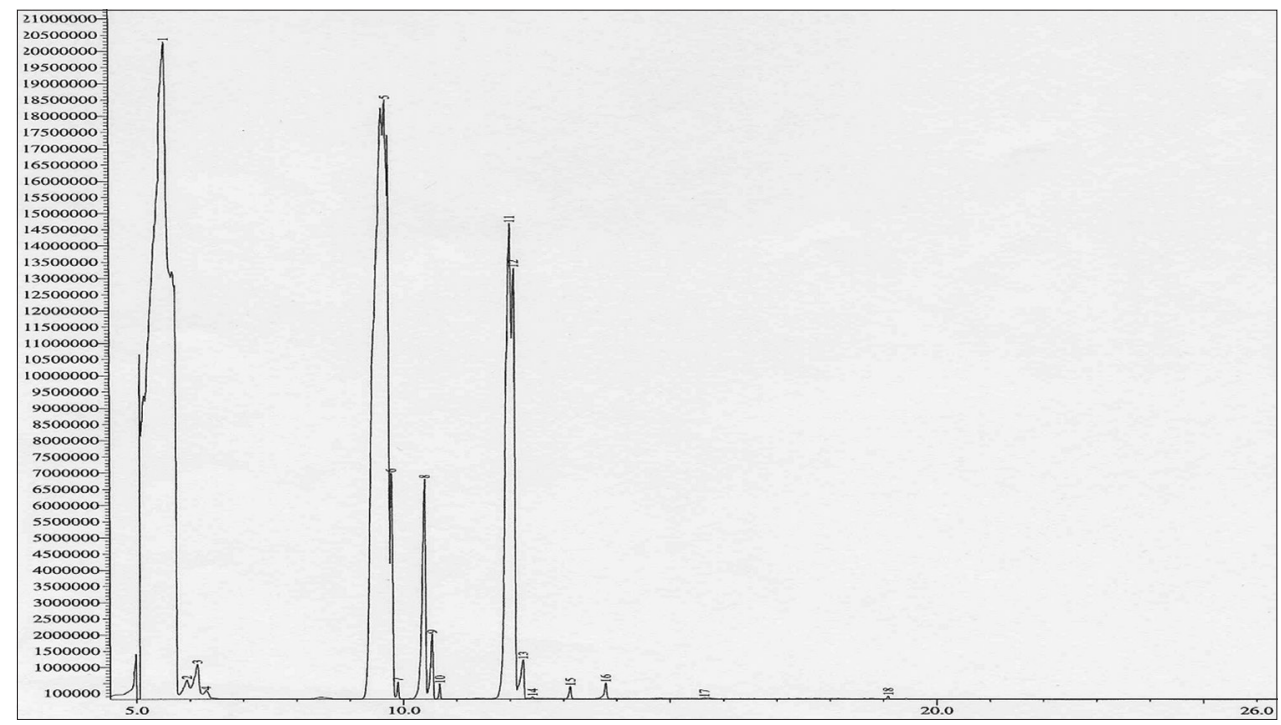

Fig. 1: Gas chromatography chromatogram of essential oils of Rosmarinus officinalis from Diyala, IraqFGC

Table 1: Chemical composition of essential oils of Rosmarinus officinalis from Diyala, Iraq

\begin{tabular}{|c|c|c|c|c|}
\hline Peak No. & Time & $\%$ composition & Compound name(s) & IUPAC \\
\hline 1. & 5.54 & 59.02 & Eucalyptol (1,8-Cineole) & 1,3,3-trimethyl-2-oxabicyclo[2.2.2]octane \\
\hline 2. & 5.94 & 0.17 & 3-Heptanone, 5-methyl- & 5-methylheptan-3-one \\
\hline 3. & 6.13 & 0.39 & 3,6-Octadecadiynoic acid, methyl ester & methyl octadeca-3,6-diynoate \\
\hline 4. & 6.29 & 0.07 & Cosmene & (3E,5E)-2,6-dimethylocta-1,3,5,7-tetraene \\
\hline 5. & 9.68 & 29.09 & L-Camphor & (1S)-1,7,7-trimethylbicyclo[2.2.1] heptan-2-one \\
\hline 6. & 9.78 & 1.22 & Linalool & 3,7-dimethylocta-1,6-dien-3-ol \\
\hline 7. & 9.90 & 0.08 & Cyclohexylmethanol, trifluoroacetate (ester) & Cyclohexylmethyl trifluoroacetate \\
\hline 8. & 10.41 & 2.83 & Bornyl acetate & 1,7,7-trimethyl-2-bicyclo[2.2.1] heptanyl acetate \\
\hline 9. & 10.54 & 0.65 & $\beta$-Terpineol & 1-methyl-4-prop-1-en-2-ylcyclohexan-1-ol \\
\hline 10. & 10.68 & 0.07 & $\begin{array}{l}\text { Preg-4-en-3-one, 17.alpha.-hydroxy-17.beta.- } \\
\text { cyano-; } \\
\text { 17-Hydroxy-3-oxoandrost-4-ene-17-carbonitrile; }\end{array}$ & $\begin{array}{l}\text { 17-hydroxy-10,13-dimethyl-3-oxo- } \\
\text { 2,6,7,8,9,11,12,14,15,16-decahydro-1H-cyclopenta[a] } \\
\text { phenanthrene-17-carbonitrile }\end{array}$ \\
\hline 11. & 12.01 & 3.75 & $\alpha$-Terpineol & 2-(4-methylcyclohex-3-en-1-yl)propan-2-ol \\
\hline 12. & 12.09 & 1.96 & Borneol & (1S,2R,4S)-1,7,7-trimethylbicyclo[2.2.1]heptan-2-ol \\
\hline 13. & 12.24 & 0.42 & $\begin{array}{l}\text { Bicyclo[5.1.0]octane, 8-(1-methylethylidene)- } \\
\text {;8-(1-Methylethylidene)bicyclo[5.1.0]octane;8- } \\
\text { propan-2-ylidenebicyclo[5.1.0]octane }\end{array}$ & 8-propan-2-ylidenebicyclo[5.1.0] octane \\
\hline 14. & 12.42 & 0.01 & {$\left[1,1^{\prime}\right.$-Bicyclopentyl]-2-ol } & 2-cyclopentylcyclopentan-1-ol \\
\hline 15. & 13.13 & 0.11 & Bicyclo[2.2.0] hexane-1-carboxaldehyde & Bicyclo[2.2.0]hexane-1-carbaldehyde \\
\hline 16. & 13.79 & 0.14 & Dihydromyrcene & (3R)-3,7-dimethylocta-1,6-diene \\
\hline 17. & 15.64 & 0.02 & Verbenone & (1R)-cis-4,6,6-Trimethylbicyclo[3.1.1]hept-3-en-2-one \\
\hline \multirow[t]{2}{*}{18.} & 19.09 & 0.02 & Longipinene epoxide & $\begin{array}{l}\text { 1,3,9,9-tetramethyl-4-oxatetracyclo[5.5.0.02,8.03,5] } \\
\text { dodecane }\end{array}$ \\
\hline & & 100.00 & & \\
\hline
\end{tabular}




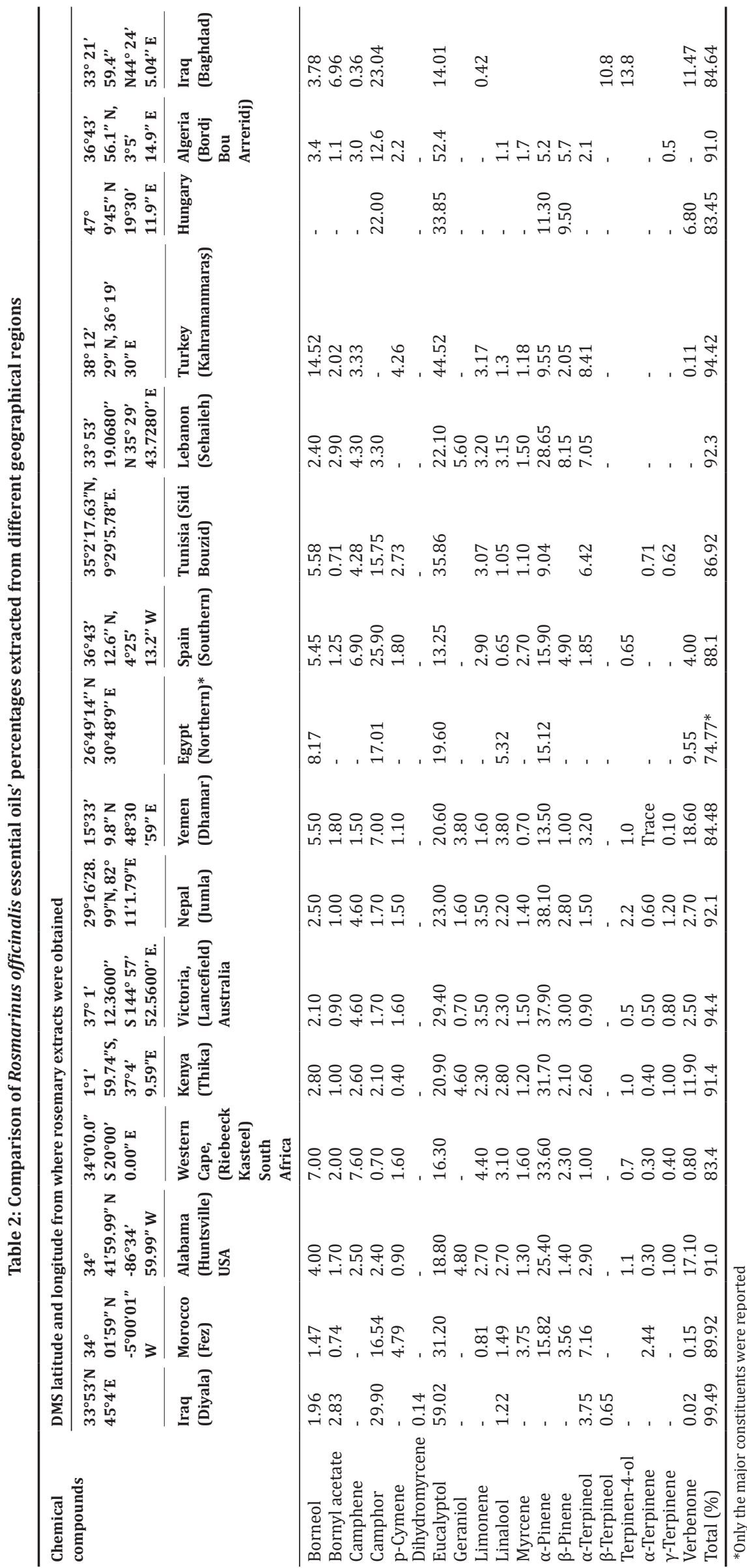


The two major components in rosemary extract from Diyala Province of the eastern side of Iraq were eucalyptol (1,8-cineole) and L-camphor, and they represent $59 \%$ and $29 \%$, respectively (Table 1 ). In addition, $\alpha$-terpineol, bornyl acetate, borneol, linalool, and $\beta$-terpineol were detected in $3.75,2.83,1.96,1.22$, and $0.65 \%$, respectively (Table 1 ). Similarly, in 8 out of 15 studies presented in Table 2 showed that eucalyptol (1,8-cineole) (20-52\%) is the major constituent of $R$. officinalis essential oils that were harvested from Morocco [10], Algeria [12], Hungary [13], Yemen [6], Egypt [14], Turkey [3], and Tunisia [15]. Besides, in the other 6 out of 15 studies presented, eucalyptol (1,8-cineole) (16-29\%) is the second major constituent of rosemary from Lebanon, Alabama (USA), Western Cape (South Africa), Nepal, Victoria (Australia), and Kenya [6,16]. In addition, other studies have shown comparable results by identifying 1,8-cineole to be the major essential oil from rosemary harvested from different areas in Morocco and Algeria [17,18]. Camphor, on the other hand, is the second major essential oil constituent identified in an Iraqi, Diyala Province (29.9\%), and the first in Baghdad (23.04\%) (Table 2). Besides, camphor has also been shown to be a significant constituent of rosemary essential oil (16-26\%) in Hungary [13], Southern Spain [1,19], Morocco [10,20], Algeria [12], Tunisia [15], and Egypt [14].

One of the surprising results in the present study is that one of the major hydrocarbon monoterpenes, $\alpha$-pinene, was not detected. In some geographical locations, such as Alabama (USA), Western Cape (South Africa), Nepal, Victoria (Australia), Kenya, and Lebanon, $\alpha$-pinene has been found to be a significant constituent of rosemary essential oils ranging from $25 \%$ to $38 \%$ [6]. Furthermore, $\alpha$-pinene has been detected, but in a much lesser percentage (3-16\%) in other countries as well (Table 2). In the present study, on the other hand, hydrocarbon monoterpenes represent $<1 \%$, whereas more than $96 \%$ of the essential constituents are oxygenated monoterpenes such as eucalyptol, camphor, $\alpha$-terpineol, borneol, linalool, $\beta$-terpineol, and verbenone (Tables 1 and 2). It has been established that monoterpenes undergo an atmospheric transformation which is likely considered the main leading geographic cause of a fundamental change within the same species. However, a good number of documents have shown that bacteria play an essential in monoterpenes transformation as well [21]. Bacteria use monoterpenes as a carbon and energy source, and for instance, Serratia marcescens utilizes pinene and transforms it into $\alpha$-terpineol $[21,22]$. This opens a new insight into how bacteria play in monoterpenes transformation that would alter the constituents of extracted essential oils. Therefore, it should be suggested to perform microbial culture on every extract while performing chemotypic characterization. Furthermore, more studies on the key enzymes that facilitate monoterpenes transformation and metabolism by bacterial contamination would clarify the discrepancy in the chemotypic characterization of rosemary essential oil between close geographical locations.

\section{CONCLUSION}

The present study showed that rosemary essential oil from Diyala Province of Iraq consists mostly of oxygenated monoterpenes ( $>96 \%$ ). The oxygenated monoterpenes are mainly eucalyptol (1,8-cineole) and L-camphor, in which they represent $88 \%$ of the essential oil extracted.

\section{CONFLICTS OF INTEREST}

The author has no conflicts of interest to share.

\section{REFERENCES}

1. Begum A, Sandhya S, Shaffath Ali S, Vinod KR, Reddy S, Banji D. An in-depth review on the medicinal flora Rosmarinus officinalis (Lamiaceae). Acta Sci Pol Technol Aliment 2013;12:61-73.
2. Andrade JM, Faustino C, Garcia C, Ladeiras D, Reis CP, Rijo P. Rosmarinus officinalis $\mathrm{L}$.: An update review of its phytochemistry and biological activity. Future Sci OA 2018;4:FSO283.

3. Nieto G, Ros G, Castillo J. Antioxidant and antimicrobial properties of rosemary (Rosmarinus officinalis, L.): A review. Medicines (Basel) 2018;5:98

4. Yu N, Sun YT, Su XM, He M, Dai B, Kang J. Treatment with eucalyptol mitigates cigarette smoke-induced lung injury through suppressing ICAM-1 gene expression. Biosci Rep 2018;38:BSR20171636.

5. Ozcan MM, Chalchat JC. Chemical composition and antifungal activity of rosemary (Rosmarinus officinalis L.) oil from Turkey. Int J Food Sci Nutr 2008;59:691-8.

6. Satyal P, Jones TH, Lopez EM, McFeeters RL, Ali NA, Mansi I, et al. Chemotypic characterization and biological activity of Rosmarinus officinalis. Foods 2017;6:E20.

7. Yildirm D. The effect of seasonal variation on Rosmarinus officinalis (L.) essential oil composition. Int J Agric Wildlife Sci 2018;4:33-8.

8. Jawad AM, Allawi AK, Ewadh HM. Essential oils of rosemary as antimicrobial agent against three types of bacteria. Med J Babylon 2018:15:53-6.

9. Tawfeeq AA, Mahdi MF, Abaas IS, Alwan AH. Isolation, quantification, and identification of rosmarinic acid, gas chromatography-mass spectrometry of essential oil, cytotoxic effect, and antimicrobial investigation of Rosmarinus officinalis leaves. Asian J Pharm Clin Res 2018;11:126-32.

10. Elyemni M, Louaste B, Nechad I, Elkamli T, Bouia A, Taleb M, et al. Extraction of essential oils of Rosmarinus officinalis L. by two different methods: Hydrodistillation and microwave assisted hydrodistillation. ScientificWorldJournal 2019;2019:3659432.

11. Waithaka PN, Gathuru EM, Githaiga BM, Kimani SN. Control of passion fruit fungal diseases using essential oils extracted from rosemary (Rosmarinus officinalis) and Eucalyptus (Eucalyptus agglomerata) in egerton university main campus Njoro, Kenya. Int J Microbiol 2017;2017:2814581.

12. Boutekedjiret C, Bentahar F, Belabbes R, Bessiere JM. The essential Oil from Rosmarinus officinalis L. in Algeria. J Essential Oil Res 1998:6:680-2.

13. Domokos J, Hethelyi E, Palinkas J, Szirmai S, Tulok MH. Essential oil of rosemary (Rosmarinus officinalis L.) of hungarian origin. J Essent Oil Res 1997;9:41-5.

14. Elansary HO, Abdelgaleil SAM, Mahmoud EA, Yessoufou K, Elhindi K, El-Hendawy S. Effective antioxidant, antimicrobial and anticancer activities of essential oils of horticultural aromatic crops in northern Egypt. BMC Complement Altern Med 2018;18:214

15. Hcini K, Sotomayor JA, Jordan S, Bouzid S. Chemical composition of the essential oil of rosemary (Rosmarinus officinalis L.) of tunisian origin. Asian J Chem 2013;25:2601-3.

16. Diab Y, Auezova L, Chebib H, Chalchat JC, Figueredo G. Chemical composition of lebanese rosemary (Rosmarinus officinalis L.) essential oil as a function of the geographical region and the harvest time. J Essent Oil Res 2002;14:449-52.

17. Chalchat JC, Garry RP, Michet A, Benjilali B, Chabart JL. Essential oils of rosemary (Rosmarinus officinalis L.). The chemical composition of oils of various origins (Morocco, Spain, France). J Essent Oil Res 2011;25:613-8

18. Djebir S, Ksouri S, Trigui M, Tounsi S, Boumaaza A, Hadef Y, et al. Chemical composition and acaricidal activity of the essential oils of some plant species of Lamiaceae and Myrtaceae against the vector of tropical bovine theileriosis: Hyalomma scupense (syn. Hyalomma detritum). Biomed Res Int 2019;2019:7805467.

19. Salido S, Altarejos J, Nogueras M, Sanchez A, Lugue P. Chemical composition and seasonal variations of rosemary oil from southern Spain. J Essen Oil Res 2003;15:10-14.

20. Haida S, Essadik FZ, Kribii A, Habsaoui A, Ounine K, Benmoumen A, et al. Study of chemical composition of rosemary essential oil from western Morocco and evaluation of antioxidant and antibacterial activity of its extracts. World J Pharm Res 2015;4:303-23.

21. Marmulla R, Harder J. Microbial monoterpene transformations-a review. Front Microbiol 2014:5:346.

22. Wright SJ, Caunt P, Carter D, Baker PB. Microbial oxidation of a-pinene by Serratia marcescens. Appl Microbiol Biotechnol 1986;23:224-7. 